\title{
Research of Effect on Gasoline-2-Propanol Blends on Exhaust Emission of Gasoline Engine with Direct Injection Using Taguchi Approach
}

\author{
Ekrem Tasoren $^{* 1}\left(\mathbb{B}\right.$, Hasan Aydogan ${ }^{2}(\mathbb{B})$, Mehmet Selman Gokmen ${ }^{3 *}(\mathbb{C})$ \\ 'Selcuk University, Faculty of Technology, Department of Mechanical, Konya Turkey \\ ${ }^{2}$ Selcuk University, Faculty of Technology, Department of Mechanical Engineering, Konya, Turkey \\ ${ }^{3}$ Necmettin Erbakan University, Seydişehir Vocational School, Konya, Turkey
}

\begin{abstract}
One of the most important causes of global warming is the greenhouse gas effect caused by the increased $\mathrm{CO}_{2}$ emission due to the use of petroleum-based fuels in internal combustion engines. $\mathrm{O}_{2}, \mathrm{H}_{2} \mathrm{O}, \mathrm{NO}_{\mathrm{x}}$ emissions released as a result of the combustion reaction and released into the atmosphere from the exhaust turn into nitric acid $\left(\mathrm{HNO}_{3}\right)$ as a result of some reactions taking place in nature. In addition, the $\mathrm{OH}$ radicals released as a result of these reactions that can not turn into nitric acid react with the ozone layer $\left(\mathrm{O}_{3}\right)$ and support the formation of hydroperoxyl $\left(\mathrm{HO}_{2}\right)$, which causes a harmful emission cycle. $\mathrm{CO}$ emissions, on the other hand, react with $\mathrm{O}_{2}$ and $\mathrm{NO}_{\mathrm{X}}$ and pollute the water vapor in the air, causing the $\mathrm{O}_{2}$ level to drop. Despite quite a lot of work done to date, it is known that due to the increase in the number of gasoline engines, their environmental damage is excessive. In this study, the effect of 2-Propanol / Gasoline fuel mixtures on exhaust emission values has been experimentally investigated using Taguchi Approach. The input factors for Taguchi Approach are 2-Propanol ratio and Engine speed and output values are determined as carbon monoxide (CO), carbon dioxide $\left(\mathrm{CO}_{2}\right)$, hydrocarbon $(\mathrm{HC})$, Nitrogen Oxide $\left(\mathrm{NO}_{\mathrm{X}}\right)$, and Oxygen $\left(\mathrm{O}_{2}\right)$ emissions. In the created Taguchi design, experiments were planned by using an L9 orthogonal array. The engine speed was determined as 1500, 2500, and $3500(\mathrm{rpm})$, and 2-propanol ratio was determined as $5 \%, 10 \%$, and $15 \%$ (\% by volume). Tests were conducted under partial load conditions. In tests conducted at $1500 \mathrm{rpm}, \mathrm{CO}$ emissions decreased by $41.99 \%$ compared to gasoline, while $\mathrm{CO}_{2}, \mathrm{HC}, \mathrm{NO}_{x}$, and $\mathrm{O}_{2}$ emissions decreased by 7,09\%, 20,91\%, 8.64\%, and 20.34\%, respectively. $2500 \mathrm{rpm}$ test, $\mathrm{CO}, \mathrm{CO}_{2}, \mathrm{HC}, \mathrm{O}_{2}$, and $\mathrm{NO}_{x}$ reductions in emissions, respectively $16.60 \%, 2.09 \%, 17.39 \%, 10.64 \%$, and $27.14 \% 3500 \mathrm{rpm}$, while the rate of decrease of the emission test values, respectively $25.30 \%, 4.88 \%, 29.09 \%$, $9.72 \%$, and $37.09 \%$ has been found in.
\end{abstract}

Keywords: Direct Injection, 2-Propanol, Exhaust Emissions, Taguchi Approach

\section{INTRODUCTION}

One of the most critical problems of today is environmental pollution. One of the primary sources of environmental pollution is the use of fossil fuels [1]. Fossil fuels are primarily used in internal combustion engines. Using biomass fuels instead of fossil fuels in these engines may reduce environmental pollution [2].

For engines that use gasoline as fuel, alcohol is considered a good biomass fuel. Alcohols obtained by biochemical processes have an alternative fuel potential with an excess oxygen content, renewable, and cleaner-burning [3]. Alcohols with a lower molecular weight than gasoline can significantly improve engine emissions when mixed with gasoline.
Alcohols contain specific amounts of oxygen in their structures $[4,5]$. Alcohols have a smaller molecular structure than engine fuels, have oxygen in their structure, do not contain sulfur, carcinogenic substances, and heavy metals found in engine fuels, causing positive effects on exhaust emissions [6]. In this way, brighter and faster combustion is provided. Increasing the combustion speed improves combustion efficiency and ensures a more stable operation of the engine. In addition, by achieving high compression rates with fast combustion, efficiency can be increased without engine knock [7]. One of the alcohols that can be used as fuel in engines is 2-Propanol. It contains three carbons in the structure of 2-Propanol, defined by the formula $\mathrm{C}_{3} \mathrm{H}_{7} \mathrm{OH}$. In addition, due to the presence of $\mathrm{OH}$ in its structure, it increases
* Corresponding author

Email: tasorenekrem@gmail.com
European Mechanical Science (2021), 5(4): 177-182

doi: https://doi.org/10.26701/ems.962605

Received: July 5, 2021

Accepted: September 8, 2021 
the oxygen content of gasoline when added to gasoline [8]. 2-Propanol is a colorless, flammable, organic compound. 2-Propanol is well mixed with many solvents, including water. It is a volatile chemical 2-Propanol fuel, also known as isopropanol [9].

In a study conducted by Keskin and Guru [9], gasoline fuel in a four-stroke spark plug ignition engine 4\%, $8 \%, 12 \%, 16 \%$, $20 \%$ added ethanol in its proportions. Additionally, 4\%, $8 \%$, $12 \%, 16 \%$, and \%20 2-Propanol was added to gasoline fuel. By experimenting with the resulting fuels, they investigated the effect of the engine on exhaust and noise emissions. As a result of the experiments, they stated that $\mathrm{HC}$ and $\mathrm{CO}$ emissions decreased and $\mathrm{NOx}$ and $\mathrm{CO}_{2}$ emissions increased using fuels added 2-Propanol.

Altun et al. [10] 5\% and 10\% 2-Propanol were added to gasoline fuel in a spark plug engine. They investigated the effect of fuel blends on exhaust emissions. As a result of the study, $\mathrm{CO}$ and $\mathrm{HC}$ observed decreased emission values while $\mathrm{CO}_{2}$ emissions increased.

In a study conducted by Mourad and Mahmoud [8], propanol was added to gasoline fuel in 5\%, 10\%, 15\%, and 20\% by volume. They evaluated the performance of a spark plug engine using fuel blends. Their results stated that particular fuel consumption decreased by about $2.84 \%$, exhaust emissions decreased by $4.18 \%$ in $\mathrm{HC}$ values, and $10.87 \%$ in $\mathrm{CO}$ values.

Simsek et al. [6] their study first added 20\% n-Propanol and 2-Propanol to gasoline fuel in a spark plug engine. In the second stage, they examined $1-3 \%$ hexane addition to previous fuels on engine performance and emissions. The emission results obtained stated a significant decrease in $\mathrm{HC}$ and $\mathrm{CO}$ emissions compared to gasoline fuel, there was no significant change in $\mathrm{NO}_{\mathrm{x}}$ emissions, and there was an increase in $\mathrm{CO}_{2}$ emissions.

In this study, changes in the exhaust emission values of a direct injection engine were examined by adding 2-Propanol by $5 \%, 10 \%$, and $15 \%$ volumetric to gasoline fuel. In this study, researches were taken into consideration while determining the fuel blends. But there is no such study on direct injection engines. For this reason, it was increased up to $15 \%$ while preparing fuel blends.

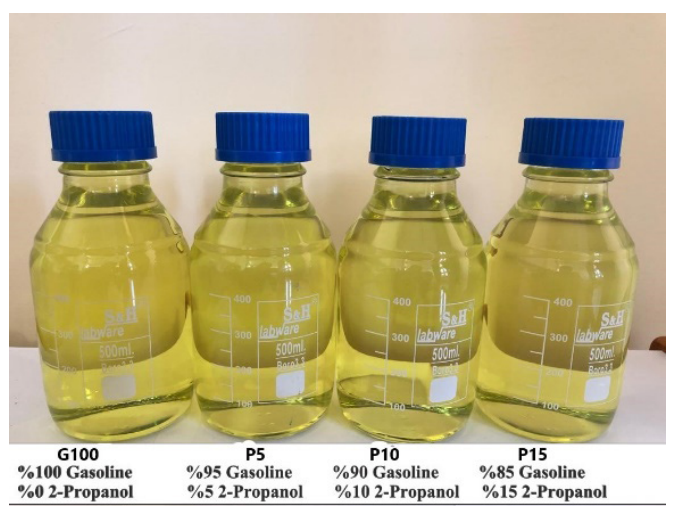

Figure 1. Test fuels
In addition, with this study, unlike other studies in the literature, the number of tests was reduced by using the Taguchi method, and the effects of 2-Propanol and engine speed values on each emission parameter were obtained as mathematical functions. Apart from this, the test intervals were visualized with contour graphics and it was determined at which ratios of 2-Propanol use was more appropriate according to the engine speed. This study comprehensively covers the effects of 2-Propanol and engine speed on emissions and forms a reference for future research.

\section{MATERIAL AND METHOD}

\subsection{Fuel blends and Test Setup}

Fuel blends were obtained by blend 2-Propanol supplied by Sigma Aldrich with 5\% (P5), 10\% (P10), and 15\% (P15) gasoline by volume. In addition, 95 octane gasoline was used as a fuel for comparison. Fuel properties are given in Table $1[3,9]$. Test fuels are shown in Figure 1. During the experiment, the fuels were mixed continuously with a mechanical mixer. As a result, phase separation is prevented.

Table 1. Fuel properties [3,9]

\begin{tabular}{|c|c|c|}
\hline Property & Gasoline & 2-Propanol \\
\hline Density $(\mathrm{g} / \mathrm{ml})$ & 0.775 & 0.786 \\
\hline Flash Point $\left({ }^{\circ} \mathrm{C}\right)$ & $<-40$ & 12 \\
\hline Autoignition Temperature $\left({ }^{\circ} \mathrm{C}\right)$ & $>250$ & 425 \\
\hline Boiling Point & $>32$ & 82.6 \\
\hline Octane Number & 95 & 95 \\
\hline Lower Heating Value $(\mathrm{kJ} / \mathrm{kg})$ & 43430 & 31000 \\
\hline
\end{tabular}

The tests were carried out under partial load using a 1.2 TSI direct injection, 4-stroke, and 4-cylinder gasoline engine, using the BT-190 FR hydraulic dynamometer at 1500, 2500, and $3500 \mathrm{rpm}$. Dynamometer properties are given in Table 2. The properties of the test engine are given in Table 3 , and the experimental setup is given in Figure 2.

Table 2. Hydraulic dynamometer specifications

\begin{tabular}{|c|c|}
\hline Feature & Capacity \\
\hline Maximum Braking Power & $100 \mathrm{~kW}$ \\
\hline Maximum Speed & $6000 \mathrm{rpm}$ \\
\hline Maximum Torque & $750 \mathrm{Nm}$ \\
\hline Brake Water Working Pressure & $0-2 \mathrm{~kg} / \mathrm{cm}^{2}$ \\
\hline Water Requirement for Maximum Power & $2.3 \mathrm{~m}^{3} / \mathrm{h}$ \\
\hline Maximum Brake Water Outlet Temperature & $80^{\circ} \mathrm{C}$ \\
\hline Torque Measurement & Electronic Load-Cell \\
\hline Rotation Direction & Right and Left \\
\hline
\end{tabular}

Table 3. Test engine technical specifications

\begin{tabular}{|c|c|}
\hline Feature & Property \\
\hline Volume & $1197 \mathrm{~cm}^{3}$ \\
\hline Number of Cylinders & 4 \\
\hline Compression Rate & $10: 1$ \\
\hline Cylinder Diameter & $71 \mathrm{~mm}$ \\
\hline Stroke & $75.6 \mathrm{~mm}$ \\
\hline Maximum Power Output & $77 \mathrm{~kW}($ @5000 rpm) \\
\hline Maximum Torque & $175 \mathrm{Nm}(@ 1500-3500)$ \\
\hline Emission Standard & Euro 5 \\
\hline Control Unit & Continental Simos 10.1 \\
\hline
\end{tabular}


For the measurement of exhaust emissions, the Bosch BEA350 model emission meter was used in the experiments. The specification values of the emission meter are given in Table 4.

Table 4. Emission meter specifications
\begin{tabular}{|c|c|c|}
\hline Emission & Measure Range & Precision \\
\hline $\mathrm{CO}$ & $0-10(\%)$ volumetric & $0.001 \%$ \\
\hline $\mathrm{CO}_{2}$ & $0-18(\%)$ volumetric & $0.01 \%$ \\
\hline $\mathrm{HC}$ & $0-9999 \mathrm{ppm}$ volumetric & $1 \mathrm{ppm}$ \\
\hline $\mathrm{NO}_{\mathrm{x}}$ & $0-5000 \mathrm{ppm}$ volumetric & $1 \mathrm{ppm}$ \\
\hline $\mathrm{O}_{2}$ & $0-22(\%)$ volumetric & $0.01 \%$ \\
\hline
\end{tabular}

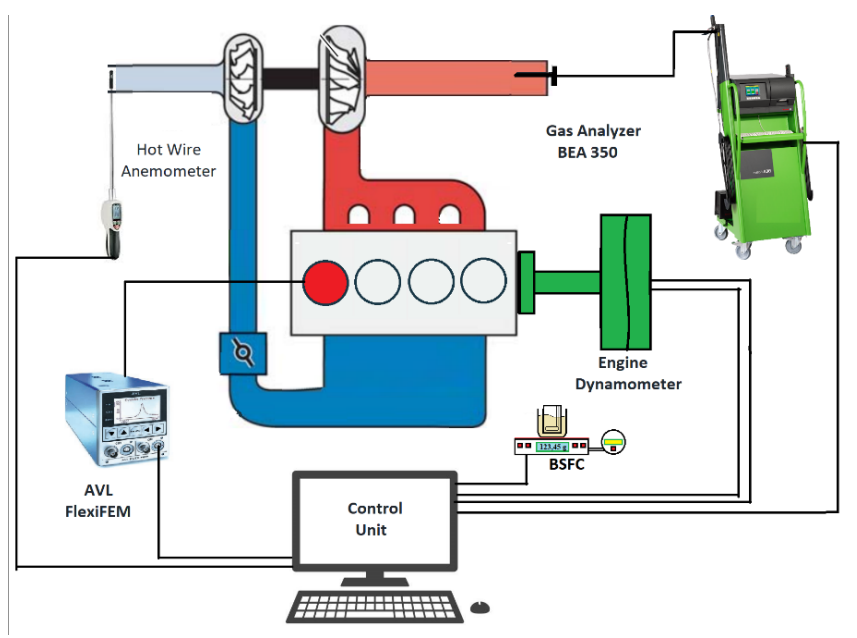

Figure 2. Experimental setup

\subsection{Taguchi Experimental Design}

Experimental design techniques (DoE), reducing costs by reducing the number of tests, determining input values at different levels (small, medium, most prominent, etc.) instead of performing tests in the whole range, only to investigate the effect of these values on the response values and to analyze the results mathematically depending on the estimation functions and used to express. Taguchi's experimental design technique is one of the DoE methods developed by Dr. Genichi Taguchi. In this study, 2-Propanol and engine speed were determined as input parameters, while $\mathrm{CO}, \mathrm{CO}_{2}$, $\mathrm{HC}, \mathrm{NO}_{\mathrm{X}}$, and $\mathrm{O}_{2}$ values were determined as output parameters. In table 4, the levels of input parameters are given.

Table 4. Taguchi method factors and level

\begin{tabular}{|c|c|c|c|}
\hline Factors & Level 1 & Level 2 & Level 3 \\
\hline A-Engine Speed (rpm) & 1500 & 2500 & 3500 \\
\hline B-2PR (\% volume) & 5 & 10 & 15 \\
\hline
\end{tabular}

Unlike other statistical designs, the Signal/Noise $(\mathrm{S} / \mathrm{N})$ ratio is used in the Taguchi design. This parameter is calculated depending on the effect of the output values on the design (lowest best, highest best, nominal best). Since all output values were wanted to be the lowest in this study, the S/N ratio was calculated as given in Equation 1, with the Y output value, the I level, and $\mathrm{n}$ is the number of combinations at the O Level. In addition, the L9 orthogonal sequence was used depending on the levels of parameters and parameters, and a total of 9 measurements were made consisting of 3 levels of each input parameter and combinations of these levels. The measurement values were compared with the gasoline fuel values.

$$
\frac{S}{N}=-10 \log \left(\frac{1}{n} \sum_{i=1}^{n} y_{i}^{2}\right)
$$

Different from traditional statistical mathematical approaches to obtain mathematical function of a test procedure as the test procedure to predict output values for input values that are not included in the prediction function $y, \beta$ constant-coefficient, $\mathrm{k}$ the number of input factors, $\mathrm{X}$ to represent the input value and the standard error is given by equation 2 , it is stated that[11]. Functions that cannot be explained linearly are expressed as I linear; J is given in equation 3 to represent the polynomial coefficient [12].

$$
\begin{aligned}
& y=\beta_{0}+\beta_{1} X_{1}+\beta_{2} X_{2}+\beta_{k} X_{k}+\epsilon \\
& y=\beta_{0}+\sum_{i=1}^{k} \beta_{i} X_{i}+\sum_{i=1}^{k} \beta_{i i} X_{i}^{2}+\sum \sum_{i<j}^{k} \beta_{i j} X_{i} X_{j}+\epsilon
\end{aligned}
$$

\section{RESEARCH RESULTS AND DISCUSSION}

Analysis of variance (ANOVA) ensures that non-repetitive combinations of output variables are associated with input parameters due to regression. ANOVA analysis includes factors such as $R_{2}, R_{\text {adj }}{ }^{2}$, Test value $F$ (F-value), probability value (P-value), as well as statistical factors such as exponential values of factors $\left(\mathrm{A}^{2}, \mathrm{~B}^{2}, \mathrm{~A} * \mathrm{~B}\right)$. In cases where the $\mathrm{P}$-value is less than 0.05 , the result is statistically significant. In addition, the fact that the F-value is significant increases statistical significance. $R^{2}$ values, a measure of the explainability of response values with input values, are above \%97 for all emissions. In addition, in cases where there are two or more input parameters, $\mathrm{R}_{\mathrm{adj}}{ }^{2}$ is used for benchmarking,

\begin{tabular}{|c|c|c|c|c|c|c|c|c|c|c|}
\hline \multirow[t]{2}{*}{ Parameter } & \multicolumn{2}{|c|}{$\mathrm{CO}$} & \multicolumn{2}{|c|}{$\mathrm{CO}_{2}$} & \multicolumn{2}{|c|}{$\mathrm{HC}$} & \multicolumn{2}{|c|}{$\mathrm{O}_{2}$} & \multicolumn{2}{|c|}{$\mathrm{NO}_{\mathrm{x}}$} \\
\hline & P-Value & F-Value & P-Value & F-Value & P-Value & F-Value & P-Value & F- Value & P-Value & F- Value \\
\hline A & 0.0056 & 51.10 & 0.0033 & 73.40 & 0.0005 & 273.78 & 0.0146 & 26.02 & 0.0030 & 78.25 \\
\hline B & 0.0506 & 10.03 & 0.0098 & 34.69 & 0.0000 & 1160.18 & 0.0000 & 1352.46 & 0.0079 & 40.20 \\
\hline$A^{2}$ & 0.9796 & 0.00 & 0.3213 & 1.40 & 0.0741 & 7.26 & 0.4388 & 0.79 & 0.9214 & 0.01 \\
\hline$A^{*} B$ & 0.1283 & 4.35 & 0.5588 & 0.43 & 0.3751 & 1.08 & 0.1174 & 4.75 & 0.8892 & 0.02 \\
\hline$B^{2}$ & 0.0004 & 289.26 & 0.2881 & 1.66 & 0.0187 & 21.66 & 0.0006 & 227.05 & 0.5971 & 0.35 \\
\hline $\mathrm{R}^{2}$ & \multicolumn{2}{|c|}{0.9916} & \multicolumn{2}{|c|}{0.9738} & \multicolumn{2}{|c|}{0.9997} & \multicolumn{2}{|c|}{0.9981} & \multicolumn{2}{|c|}{0.9753} \\
\hline $\mathrm{R}_{\mathrm{adj}}{ }^{2}$ & \multicolumn{2}{|c|}{0.9776} & \multicolumn{2}{|c|}{0.9301} & \multicolumn{2}{|c|}{0.9993} & \multicolumn{2}{|c|}{0.9950} & \multicolumn{2}{|c|}{0.9343} \\
\hline
\end{tabular}
and Anova results are given in Table 5 for all output values.

Table 5. ANOVA Table (A: Engine Speed (rpm) B:2-Propanol Rate (\% Vol)) 
In this study, the 2nd order functions obtained depending on the input parameters for $\mathrm{CO}, \mathrm{CO}_{2}, \mathrm{HC}, \mathrm{O}_{2}$, and $\mathrm{NO}_{\mathrm{x}}$ are respectively (4), (5), (6), (7), and (8) are given in equations.

$$
\begin{aligned}
& C O=-0.533639-0.019075 * 2 P R \\
& +0.000965833 * E S+0.0000133333 * 2 P R^{2} \\
& +0.00000355 * 2 P R * E S-2.04667 E-7 * E S^{2} \\
& C O_{2}=13.0219-0.0176667 * 2 P R \\
& -0.000256667 * E S-0.00306667 * 2 P R^{2} \\
& +0.000006 * 2 P R * E S+8.33333 E-8 * E S^{2} \\
& H C=216.597-0.0833333 * 2 P R \\
& -0.0583333 * E S-0.0733333 * 2 P R^{2} \\
& +0.0001 * 2 P R * E S+0.00000316667 * E S^{2} \\
& O_{2}=4.56306-0.0504167 * 2 P R \\
& -0.002425 * E S+0.000866667 * 2 P R^{2} \\
& +0.0000075 * 2 P R * E S+3.66667 E-7 * E S^{2} \\
& N O x=1456.71-9.83333 * 2 P R \\
& -0.00466667 * E S+0.04 * 2 P R^{2} \\
& -0.0002 * 2 P R * E S-0.0000055 * E S^{2}
\end{aligned}
$$

Test studies show a decrease in all emission values in proportion to the increased amount of 2-Propanol. In tests conducted at $1500 \mathrm{rpm}, \mathrm{CO}$ emissions decreased by $41.99 \%$ compared to gasoline, while $\mathrm{CO}_{2}, \mathrm{HC}, \mathrm{NO}_{x^{\prime}}$ and $\mathrm{O}_{2}$ emissions decreased by $7,09 \%, 20,91 \%, 8.64 \%$, and $20.34 \%$, respectively. 2500 rpm test, $\mathrm{CO}, \mathrm{CO}_{2}, \mathrm{HC}, \mathrm{O}_{2}$, and $\mathrm{NO}_{x}$ reductions in emissions, respectively $16.60 \%, 2.09 \%, 17.39 \%$, $10.64 \%$, and $27.14 \% 3500 \mathrm{rpm}$, while the rate of decrease of the emission test values, respectively $25.30 \%, 4.88 \%, 29.09 \%$, $9.72 \%$, and $37.09 \%$ has been found in. Test results are given in Table 6.

In Figure 3, contour graphs obtained for all emission values are given. Contour charts are essential for determining the most suitable conditions of use for output values. $\mathrm{CO}$ emission is an important parameter that shows the chemical energy formed in incomplete combustion and cannot be converted into heat energy. In cases where there is not enough air-fuel mixture in the combustion zone, the efficiency of the combustion event decreases, and $\mathrm{CO}$ is formed as a combustion product. When the $\mathrm{CO}$ graph is examined, it is seen that as the 2-Propanol ratio in the fuel blend increases, the $\mathrm{CO}$ values decrease. Due to the presence of oxygen in the structure of 2-propanol, the amount of oxygen taken into the cylinder increases. Therefore, combustion is considered to be more efficient. The results reported by Keskin and Guru, Mourad et al. [8,9] are similar to the results of the studies.

$\mathrm{CO}_{2}$ gas is a colorless, harmless, and scentless gas. $\mathrm{CO}_{2}$ emission is a parameter that's revealed during combustion and shows complete combustion. If there is enough $\mathrm{O}_{2}$ in the combustion chamber, the fuel oxidizes, and the $\mathrm{C}$ atom in the fuel combines with $\mathrm{O}_{2}$ to form $\mathrm{CO}_{2}$ gas. When the $\mathrm{CO}_{2}$ graph is investigated, it is seen that there is a decrease in $\mathrm{CO}_{2}$ emission values due to the increase in the 2-Propanol ratio in the blend. Since 2-Propanol has fewer $\mathrm{C}$ atoms in its structure than gasoline, it is thought that $\mathrm{CO}_{2}$ emissions are lower than gasoline [13].

$\mathrm{HC}$ emissions occur in combustion products because the fuel cannot oxide or the ignition temperature is unavailable [10]. $\mathrm{HC}$ emission exhibited behavior similar to the $\mathrm{CO}_{2}$ emission value at lower engine speeds. The lowest $\mathrm{HC}$ emission values were obtained in P15 fuel at an engine speed of $3500 \mathrm{rpm}$.

\begin{tabular}{|c|c|c|c|c|c|c|}
\hline $\begin{array}{l}\text { Engine Speed } \\
\text { (rpm) }\end{array}$ & Fuel & $\begin{array}{c}\mathrm{CO} \\
(\% \mathrm{Vol})\end{array}$ & $\begin{array}{c}\mathrm{CO}_{2} \\
(\% \mathrm{Vol})\end{array}$ & $\begin{array}{c}\mathrm{HC} \\
(\mathrm{ppm})\end{array}$ & $\begin{array}{l}\mathrm{NO}_{x} \\
(\mathrm{ppm})\end{array}$ & $\begin{array}{c}\mathrm{O}_{2} \\
(\% \mathrm{Vol})\end{array}$ \\
\hline \multirow[t]{4}{*}{1500} & Gasoline & 0.412 & 12.97 & 153 & 1422 & 1.72 \\
\hline & P5 & 0.382 & 12.72 & 135 & 1396 & 1.6 \\
\hline & P10 & 0.335 & 12.37 & 129 & 1327 & 1.41 \\
\hline & P15 & 0.239 & 12.05 & 121 & 1299 & 1.37 \\
\hline \multirow[t]{4}{*}{2500} & Gasoline & 0.554 & 12.42 & 92 & 1419 & 0.70 \\
\hline & P5 & 0.545 & 12.86 & 89 & 1356 & 0.63 \\
\hline & P10 & 0.497 & 12.53 & 86 & 1312 & 0.59 \\
\hline & P15 & 0.462 & 12.16 & 76 & 1268 & 0.51 \\
\hline \multirow[t]{4}{*}{3500} & Gasoline & 0.328 & 13.11 & 55 & 1347 & 0.62 \\
\hline & P5 & 0.317 & 13.02 & 51 & 1317 & 0.47 \\
\hline & P10 & 0.262 & 12.97 & 46 & 1284 & 0.42 \\
\hline & P15 & 0.245 & 12.47 & 39 & 1216 & 0.39 \\
\hline
\end{tabular}

$\mathrm{O}_{2}$ emission exhibited behavior similar to $\mathrm{CO}_{2}$ emission value at lower engine speeds. The lowest values for $\mathrm{O}_{2}$ emission value were obtained in P15 fuel at $3500 \mathrm{rpm}$ engine speed. $\mathrm{O}_{2}$ emission is a vital parameter to see the oxygen consumed during combustion. In affluent mixing areas, $\mathrm{O}_{2}$ further improves combustion. The measurement of $\mathrm{O}_{2}$ emission shows at what rate the amount of oxygen is used during combustion [13]. An increase in the turbulence in the combustion chamber with the increase in engine speed, providing an ideal fuel-air blend, and thus better combustion, is seen as the reason for this decrease in $\mathrm{O}_{2}$ emissions. In addition, it is seen that the $\mathrm{O}_{2}$ emissions of the blends with 2-Propanol fuel are lower than the use of gasoline. Using these fuels is normal for the $\mathrm{O}_{2}$ values to decrease due to the increase in 

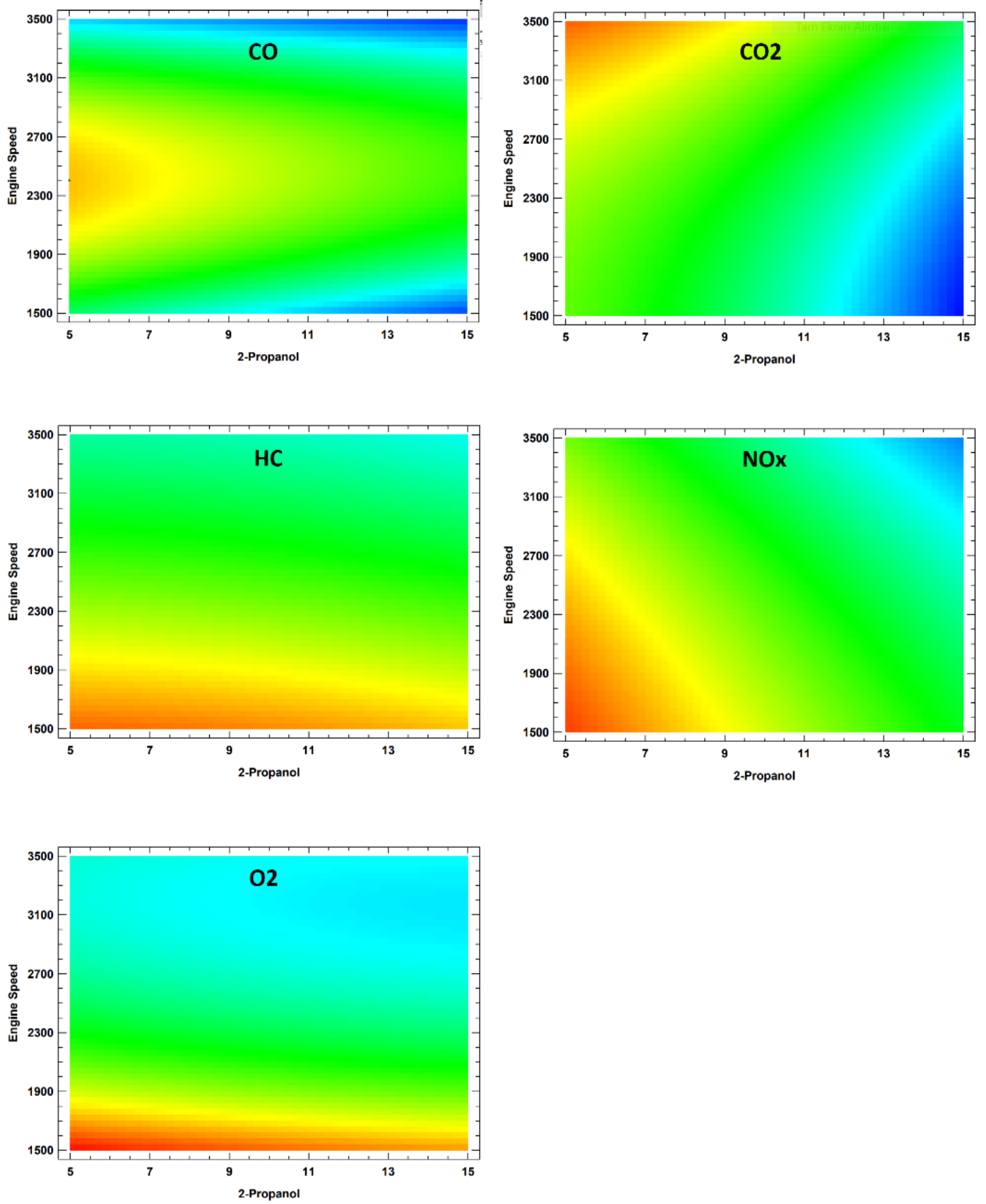

Figure 3. Contour charts for all emission values

the $\mathrm{CO}_{2}$ value.

$\mathrm{NO}_{\mathrm{x}}$ emissions occur when the nitrogen in the air is ionized and combined with oxygen as the temperature in the combustion chamber increases. Temperature, oxygen ratio, and combustion time are important parameters affecting $\mathrm{NO}_{\mathrm{x}}$ emissions [2]. When the $\mathrm{NO}_{\mathrm{x}}$ graph is examined, it is seen that $\mathrm{NO}_{\mathrm{x}}$ values decrease as the engine speed increases. As the engine speed increases, the combustion event accelerates and the intake time shortens, and sufficient oxygen cannot be taken into the cylinders. Therefore, it can be expressed as the reason that $\mathrm{NO}_{\mathrm{x}}$ formation decreases. In addition, the amount of $\mathrm{NO}_{\mathrm{x}}$ emission decreases with the increase of the 2-Propanol ratio in the blended fuels. As seen in Table 1, the lower heating value of 2-Propanol is lower than that of gasoline. As a result, it leads to a lower combustion end tem- perature in the cylinder $[2,14]$. As a result of this situation, it is thought that there is a decrease in the number of $\mathrm{NO}_{\mathrm{x}}$ emissions. While $\mathrm{NO}_{\mathrm{X}}$ emission is at its highest value up to $2700 \mathrm{rpm}$ engine speed and approximately 9\% 2-Propanol, it decreases with increasing engine speed and 2-Propanol ratio. $\mathrm{NO}_{\mathrm{X}}$ emission reaches its lowest value at $3500 \mathrm{rpm}$ engine speed and P15 fuel.

\section{CONCLUSION}

In this study, the effect of gasoline fuel mixtures containing 5\%, 10\%, and 15\% 2-Propanol on exhaust emissions at 1500, 2500 and 3500 rpm engine speeds using 1197 cc, 1.2 TSI engine was investigated experimentally and statistically. Taguchi method was used for experimental designs. Engine speed (rpm) and 2-Propanol (\%) ratios were determined as input parameters and emission values as output param- 
eters. Nine tests were performed for every three levels of input parameters, and these tests were compared with $100 \%$ gasoline. As a result of the study, emission values in 2-Propanol-gasoline fuel blends decreased at all engine speeds. 2-Propanol has a lower heating value compared to gasoline, lowers the combustion temperature, and reduces emission. In addition, the $\mathrm{OH}$ group in its chemical structure is connected to water molecules in the fuel by hydrogen bonding, and the methyl groups are connected to gasoline by dipole bonds, forming an excellent blend and contributing to the reduction of $\mathrm{CO}_{2}, \mathrm{CO}$, and $\mathrm{HC}$ emissions. With increasing engine speed, the amount of $\mathrm{O}_{2}$ per unit fuel decreases proportionally. This study obtained mathematical functions depending on the input parameters for all emission values and shown with contour graphs. The Taguchi approach in internal combustion engine tests is of great economic benefit by reducing the number of experiments, time, and material used. In addition, as a result of the study using the Taguchi approach, an approximate estimation of unknown input parameters is possible by obtaining prediction functions.

\section{Symbols and Abbreviations}

G Gasoline

HC

Hydrocarbon (ppm)

P5 95\% Gasoline + 5\% 2-Propanol

Carbon monoxide (\% by volume)

P10 90\% Gasoline + 10\% 2-Propanol

Carbon dioxide (\% by volume)

P15 85\% Gasoline + 15\% 2-Propanol Nitrous oxide (ppm)

2PR 2-Propanol

Oxygen (\% by volume)

\section{REFERENCES}

[1] Tosun, E., Ozgur, T., Ozgur, C., Ozcanli, M., Serin, H., Aydin, K., (2017), Comparative analysis of various modeling techniques for emission prediction of diesel engine fueled by diesel fuel with nanoparticle additives. European Mechanical Science 1(1): 15-23, Doi: 10.26701/ ems.320490.

[2] Tosun, E., Özcanlı, M., (2021), Hydrogen enrichment effects on performance and emission characteristics of a diesel engine operated with diesel-soybean biodiesel blends with nanoparticle addition, Engineering Science and Technology, 24: 648-654, Doi: 10.1016/j. jestch.2020.12.022.

[3] Imdadul, H.K., Masjuki, H.H., Kalam, M.A., Zulkifli, N.W.M., Alabdulkarem, A., Rashed, M.M. Teoh, Y.H., How, H.G., (2016), Higher alcohol-biodiesel-diesel blends: An approach for improving the performance, emission, and combustion of a light-duty diesel engine. Energy Conversion and Management 111: 174-185, Doi: 10.1016/j. enconman.2015.12.066.

[4] Atmanli, A., (2016), Comparative analyses of diesel-waste oil biodiesel and propanol, n-butanol or 1-pentanol blends in a diesel engine. Fuel 176: 209-215, Doi: 10.1016/j.fuel.2016.02.076.

[5] Yusoff, M.N.A.M., Zulkifli, N.W.M., Masjuki, H.H., Harith, M.H.,
Syahir, A.Z., Kalam, M.A., Mansor, M.F., Azham, A., Khuong, L.S., (2017), Performance and emission characteristics of a spark-ignition engine fuelled with butanol isomer - gasoline blends. Transportation Research Part D: Transport and Environment 57, 23 - 38, Doi: 10.1016/j.trd.2017.09.004.

[6] Şimşek, D., Oral, F., Çolak, N., (2019), The effect on engine performance and emissions of gasoline-propanol-hexane fuel blends on single-cylinder spark-ignition engines, Journal of Thermal Science and Technology, 39 (1), 81-89.

[7] Şimşek, D., Çolak, N.Y., Oral, F., (2018), Buji Ateşlemeli motorlarda kullanilan $n$-propanol ve izo-propanol / benzin yakit karişimlarinin performans ve emisyonlara etkisi, Bitlis Eren Üniversitesi Fen Bilimleri Dergisi, 7 (2): 409-416.

[8] Mourad, M., Mahmoud, K.R.M., (2018), Performance investigation of passenger vehicle fueled by propanol/gasoline blend according to a city driving cycle, Energy 149: 741-749, Doi: 10.1016/j.energy.2018.02.099.

[9] Keskin, A., Gürü, M., (2011), The effects of ethanol and propanol additions into unleaded gasoline on exhaust and noise emissions of a spark-ignition engine. Energy Sources, Part A: Recovery, Utilization and Environmental Effects 33(23): 2194-2205, Doi: 10.1080/15567030903530558.

[10] Altun, Ş., Öner, C., Firat, M., (2010), Exhaust emissions from a spark-ignition engine operating on isopropanol and unleaded gasoline blends, Technology, 13(3), 183-188.

[11] Anderson-Cook, C.M., Borror, C.M., Montgomery, D.C., (2009), Rejoinder for "Response surface design evaluation and comparison", Journal of Statistical Planning and Inference 139(2): 671-674, Doi: 10.1016/j.jspi.2008.04.009.

[12] Montgomery, D.C., (2006), Design and Analysis of Experiments, Publisher: John Wiley \& Sons, Inc.111 River Street Hoboken NJ United States, ISBN:978-0-470-08810-4.

[13] Uludamar, E., Yildizhan, Ş., Aydin, K., Özcanli, M., (2016), Vibration, noise and exhaust emissions analyses of an unmodified compression ignition engine fuelled with low sulfur diesel and biodiesel blends with hydrogen addition. International Journal of Hydrogen Energy 41(26): 11481-11490, Doi: 10.1016/j.ijhydene.2016.03.179.

[14] Akar, M.A., Bas, O., Ozgur, T., Ozcanli, M., (2018), Effect of bioethanol blending with gasoline on emissions characteristics with spark plug alteration for SI engine. Journal of Biotechnology 280: S90, Doi: 10.1016/j.jbiotec.2018.06.296. 